Suska Journal of Mathematics Education

Vol.2, No. 1, 2016, Hal. 1 - 12

\title{
Analisis Kesalahan Mahasiswa dalam Menyelesaikan Soal Geometri Analitik Bidang Materi Garis dan Lingkaran
}

\author{
Aristya Imswatama dan Nur'aini Muhassanah \\ Program Studi Pendidikan Matematika, Universitas Muhammadiyah \\ Sukabumi
}

Email: $\underline{\text { iaritsya@gmail.com }}$

*Summitted : 19-01-2016*Accepted : 19-03-2016

\begin{abstract}
ABSTRAK. Penelitian ini bertujuan untuk mengidentifikasi kesalahan mahasiswa dalam menyelesaikan soal geometri analitik bidang pada materi garis dan lingkaran. Subjek penelitian ini adalah mahasiswa pendidikan matematika semester II Universitas Muhammadiyah Sukabumi tahun akademik 2014/2015. Jenis dan pendekatan dalam penelitian ini adalah jenis penelitian deskriptif dengan pendekatan kualitatif. Adapun teknik pengumpulan data dalam penelitian ini adalah dengan metode dokumentasi, tes dan wawancara. Analisis data dilakukan dengan cara membandingkan data hasil tes geometri analitik dan data hasil wawancara. Dari hasil penelitian didapatkan kesimpulan bahwa kesalahan mahasiswa dalam meyelesaikan soal geometri analitik materi garis dan lingkaran adalah kesalahan konsep, kesalahan hitung, kesalahan strategi dan kesalahan sistematik.
\end{abstract}

Kata kunci : analisis kesalahan, garis dan lingkaran

\section{PENDAHULUAN}

Matematika adalah ilmu yang penting untuk dipelajari karena matematika merupakan ilmu yang mempunyai ciri khas sebagai ilmu yang memiliki objek 
abstrak, berpola pada pemikiran deduktif aksiomatik, dan juga berlandaskan pada kebenaran. Dengan adanya ciri khas tersebut, matematika berguna dalam menumbuh kembangkan kemampuan serta membentuk pribadi siswa. Matematika sebagai ilmu dasar juga diperlukan untuk mencapai keberhasilan yang berkualitas tinggi. Oleh karena itu matematika diajarkan pada semua jenjang sekolah, dari tingkat dasar hingga perguruan tinggi. Di samping itu matematika juga merupakan ilmu yang dapat diterapkan untuk menyelesaikan masalah dalam kehidupan sehari-hari.

Salah satu cabang dari matematika adalah geometri. James (dalam Ruseffendi, 1990:2) mengatakan bahwa geometri adalah ilmu yang berhubungan dengan bentuk dan besarnya (ukurannya) benda-benda. Sedangkan menurut Ruseffendi (1990:2) geometri itu ialah suatu sistem aksiomatik dan kumpulan generalisasi, model dan bukti tentang bentuk-bentuk benda bidang dan ruang.

Geometri merupakan matakuliah yang wajib ditempuh oleh mahasiswa Program Studi Pendidikan Matematika Universitas Muhammadiyah Sukabumi (UMMI). Dalam struktur kurikulum di Program Studi Pendidikan Matematika UMMI, matakuliah geometri dibagi menjadi 3 yaitu, matakuliah geometri analitik, geometri transformasi dan sistem geometri.

Geometri analitik merupakan matakuliah dasar dari geometri yang mempelajari mengenai bidang datar. Mata kuliah ini bertujuan untuk mengembangkan kemampuan mahasiswa memahami persamaan bangun geometri pada bidang datar (garis dan irisan kerucut) dalam bentuk persamaan vektor, kanonik, dan parameter, kedudukan garis terhadap garis lain dan kedudukan garis terhadap irisan kerucut. Sampai saat ini geometri masih menjadi matakuliah yang sulit, hal ini terlihat dari rendahnya nilai geometri analitik, geometri transformasi dan sistem geometri.

Hasil belajar mahasiswa yang tidak memenuhi harapan menunjukkan adanya permasalahan. Masalah tersebut adalah nilai yang rendah serta informasi dari beberapa mahasiswa matematika semester VI tahun ajaran 2013/2014 di Universitas Muhammadiyah Sukabumi, yang mengalami kesulitan saat mengejakan soal-soal geometri. Mereka mengungkapkan bahwa dalam proses pembelajaran geometri transformasi, mahasiswa mengalami kesulitan dalam pembuktian teorema, mengerjakan soal-soal pembuktian, penggunaan simbol, mengaplikasi jawaban ke dalam gambar serta memahami konsep geometri transformasi dan ketelitian dalam menyelesaikan soal-soal secara sistematika aljabarnya.

Geometri analitik merupakan matakuliah dasar geometri yang merupakan materi prasayarat dari geometri transformasi dan sistem geometri. Sehingga dalam penelitian ini penulis ingin menganalisis kesalahan mahasiswa dalam menyelesaikan soal konsep geometri analitik materi garis dan lingkaran pada mahasiswa pendidikan matematika semester II tahun akademik 2014/2015 di Universitas Muhammadiyah Sukabumi.

Tujuan dari penelitian ini adalah untuk mengidentifikasi kesalahan mahasiswa dalam menyelesaikan soal geometri analitik materi baris dan lingkaran. 
Dengan teridentifikasinya kesalahan tersebut maka akan didapatkan jenis-jenis kesalahan mahasiswa dalam memahami konsep geomteri analitik materi garis dan lingkaran.

Dari hasil penelitian ini diharapkan dapat memberikan petunjuk dan solusi tentang kesulitan mahasiswa dalam memahami konsep geometri serta sebagai penelitian pendahuluan dalam pengembangan bahan ajar geometri analitik.

\section{METODE PENELITIAN}

Jenis penelitian ini adalah penelitian deskriptif dengan menggunakan pendekatan kualitatif. Penelitian ini mendeskripsikan jenis-jenis kesulitan mahasiswa dalam menyelesaikan persoalan geometri analitik. Subjek penelitian ini adalah 3 orang mahasiswa pendidikan matematika semester II tahun ajaran 2014/2015 UMMI. Mahasiswa sebagai subjek penelitian dipilih berdasarkan hasil tes geometri analitik. Mahasiswa yang terpilih adalah mahasiswa yang melakukan kesalahan terbanyak dalam menyelesaikan soal tes geometri analitik.

Teknik pengumpulan data yang digunakan pada penelitian ini adalah tes geometri analitik dan wawancara. Data yang diharapkan berupa hasil pekerjaan mahasiswa langsung pada lembar soal beserta langkah-langkahnya. Tujuan tes geometri analitik adalah untuk mengetahui kesulitan mahasiswa dalam menyelesaikan persoalan geometr ianalitik. Dan wawancara dilaksanakn berdasarkan pedoman

Wawancara dilaksanakan berdasarkan pedoman wawancara yang telah disusun. Data yang diperoleh berupa jawaban-jawaban subjek penelitian secara langsung mengenai tes geometri dimensi tiga. Jawaban-jawaban subjek penelitian berdasarkan wawancara digunakan sebagai triangulasi.

Dalam penelitian ini menggunakan beberapa instrumen, yaitu :

a. Peneliti Sebagai Instrumen (Lexy, 2007:165)

Peneliti mengembangkan tes geometri analitik serta melakukan wawancara terhadap subjek penelitian. Data yang diperoleh dari penelitian disahkan melalui triangulasi kemudian peneliti menganalisis data tersebut.

b. Tes Geometri Analitik

Tes geometri dimensi analitik ini merupakan tes yang dirancang untuk keperluan mendiagnosis kesulitan mahasiswa dalam menyelesaikan persoalan geometri analitik. Berdasarkan hasil tes tersebut akan diidentifikasi jenis kesulitan siswa.

c. Pedoman Wawancara

Pedoman wawancara dirancang untuk mempermudah peneliti dalam menggali informasi siswa mengenai tes diagnostik yang berkaitan dengan geometri analitik. Pedoman wawancara yang digunakan berdasarkan hasil analisis dari jawaban tes geometri analitik. 


\section{HASIL PENELITIAN DAN PEMBAHASAN \\ Kesalahan dalam Menyelesaikan Soal Matematika}

Matematika merupakan ilmu yang terstruktur sehingga kesalahan mempelajari konsep terdahulu akan berpengaruh terhadap pemahaman konsep berikutnya. Menurut Lerner (Mulyono, 1999:262) kesalahan umum yang dilakukan siswa dalam mengerjakan tugas matematika yaitu kurangnya pengetahuan tentang simbol, kurangnya pemahaman tentang nilai tempat, penggunaan proses yang keliru, kesalahan perhitungan, dan tulisan yang tidak dapat dibaca sehingga siswa melakukan kekeliruan karena tidak mampu lagi membaca tulisannya sendiri.

Menurut Sritarti (1994:4), kesalahan siswa dalam mengerjakan soal matematika antara lain:

1. Kesalahan dalam membuat pemodelan matematika.

2. Kesalahan konsep, yaitu kesalahan dalam memahami konsep.

3. Kesalahan sistematik, yaitu kesalahan yang berkenaan dengan pemilihan yang salah atas teknik ekstrapolasi.

4. Kesalahan Strategi, yaitu kesalahan yang terjadi karena siswa memilih cara mengerjakan yang tidak tepat.

5. Kesalahan tanda, yaitu kesalahan dalam memberikan atau menulis tanda atau notasi matematika

6. Kesalahan hitung, yaitu kesalahan dalam melakukan operasi matematika.

\section{Identifikasi Jenis Kesalahan Mahasiswa dalam Mengerjakan Soal Geometri Analitik Bidang Materi Garis dan Lingkaran}

Pada bagian ini akan dijelaskan mengenai identifikasi jenis kesalahan yang dilakukan mahasiswa berdasarkan jawaban tertulis dan wawancara mahasiswa.

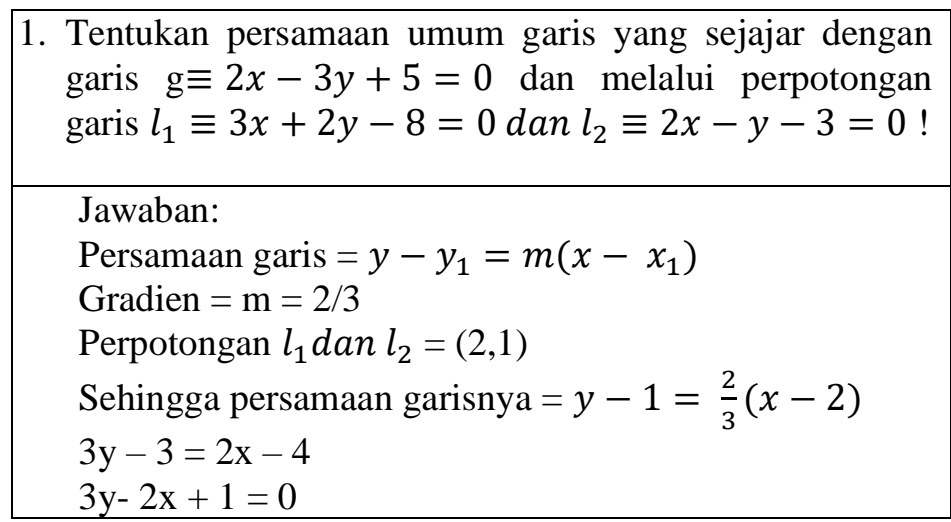

Gambar 1. Soal No.1 beserta Jawaban Benar

Berikut adalah jawaban-jawaban yang diberikan oleh subjek penelitian untuk soal no.1 : 


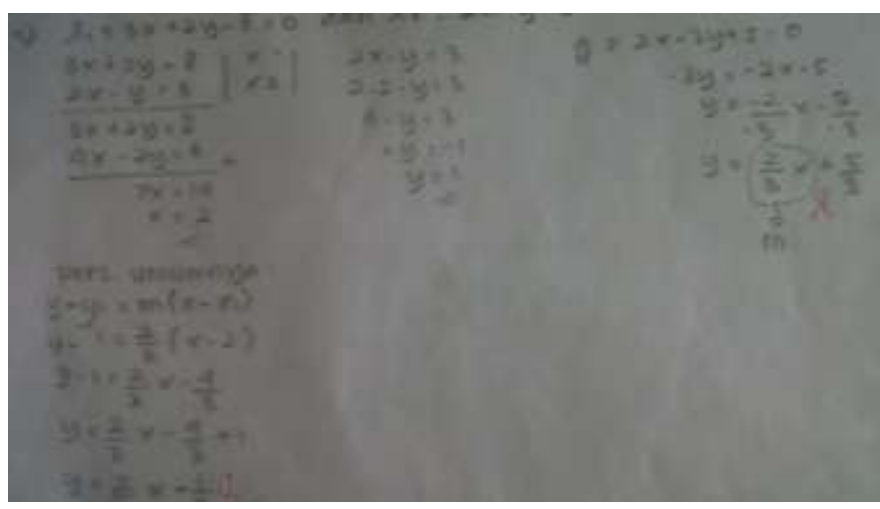

Gambar 2. Jawaban Subjek A untuk Soal No.1

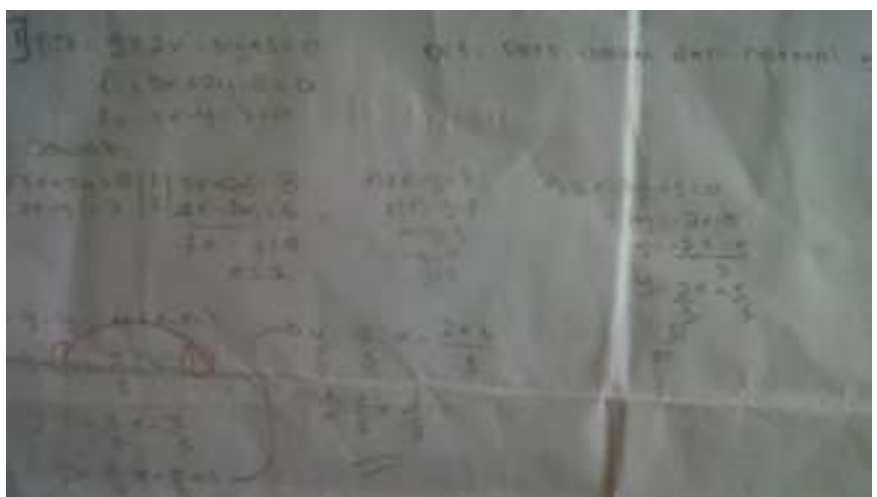

Gambar 3. Jawaban Subjek B untuk Soal No.1

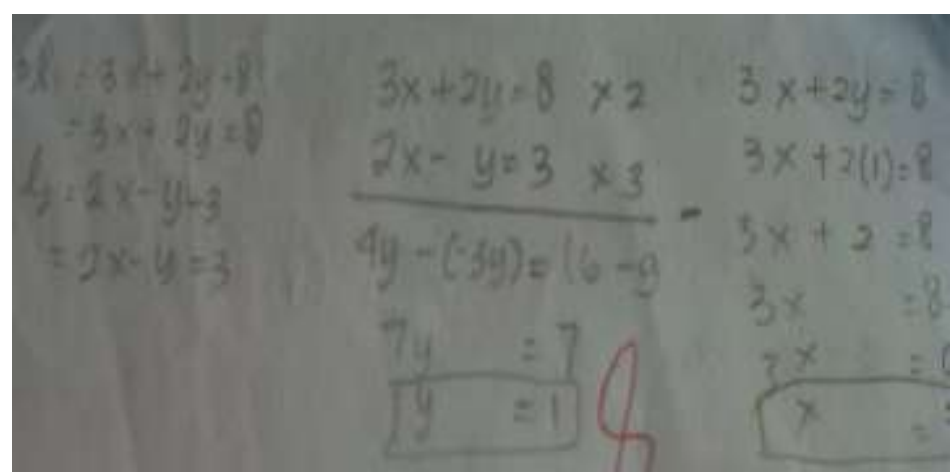

Gambar 4. Jawaban Subjek C untuk Soal No.1 
Subjek A menjawab benar soal no 1 dan tidak melakukan kesalahan. Subjek B melakukan kesalahan perhitungan dalam pengerjaan soal. Dari gambar 4,terlihat bahwa subjek $\mathrm{C}$ hanya menentukan titik potong 2 garis, dan belum menjawab pertanyaan, dapat disimpulkan bahwa subjek $\mathrm{C}$ melakukan kesalahan dalam memahami konsep.

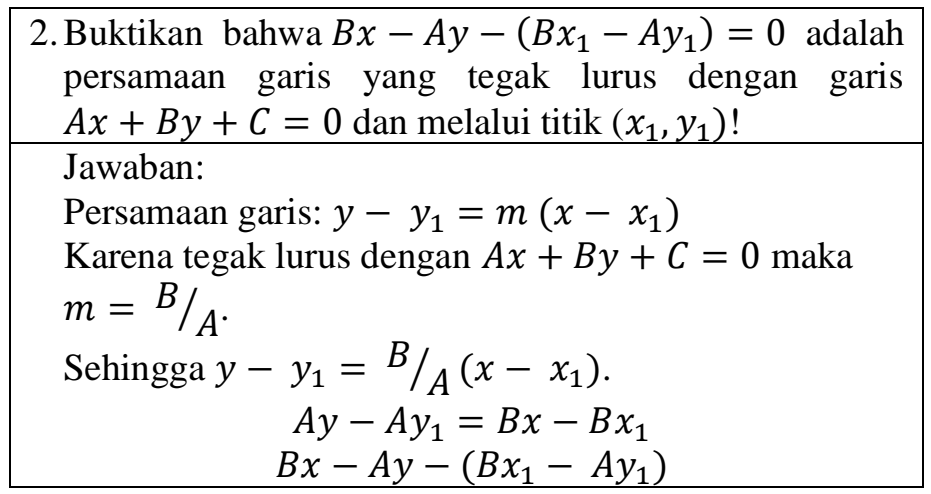

Gambar 5. Soal No.2 beserta Jawaban Benar

Berikut adalah jawaban-jawaban yang diberikan oleh subjek penelitian untuk soal no.2 :

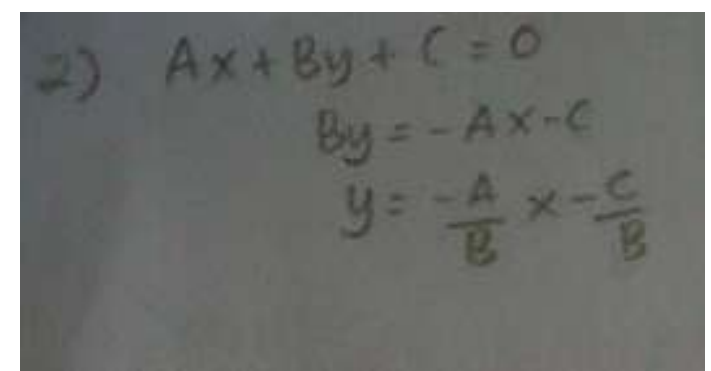

Gambar 6. Jawaban Subjek A untuk Soal No.2

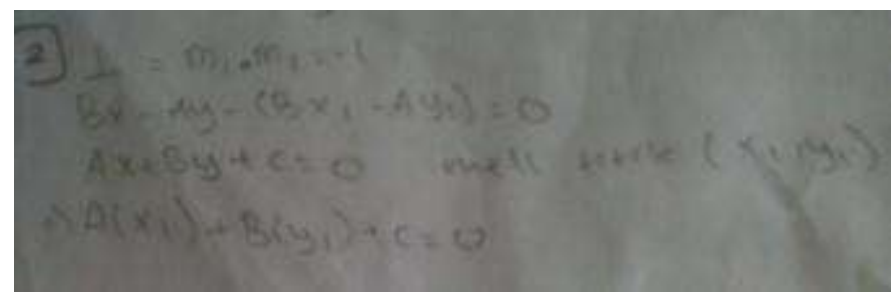

Gambar 7. Jawaban Subjek B untuk Soal No.2 
Gambar 8. Jawaban Subjek C untuk Soal No.2

Subjek A salah dalam langkah awal pengerjaan pembuktian teorema. Hal ini dapat disimpulkan bahwa subjek A melakukan kesalahan konsep. Subjek B hanya menuliskan mengenai informasi yang ada pada soal. Ini dapat disimpulkan bahwa subjek B melakukan kesalahan pemahaman konsep. Subjek C tidak mengerjakan soal no 2, dapat disimpulkan subjek $\mathrm{C}$ tidak mengetahui konsep mengenai pembuktian persamaan garis.

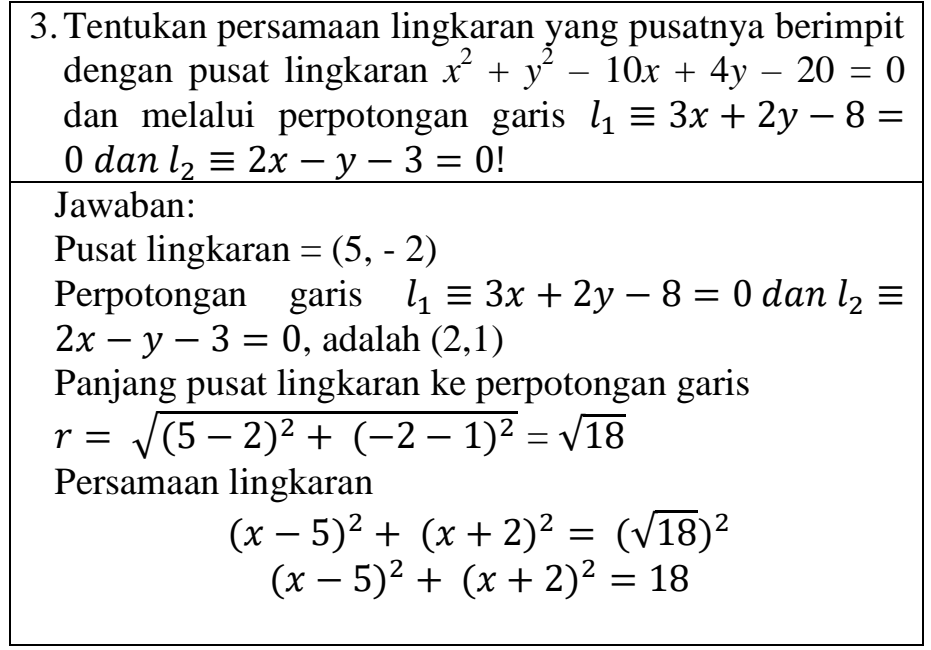

Gambar 9. Soal No.3 beserta Jawaban Benar

Berikut adalah jawaban-jawaban yang diberikan oleh subjek penelitian untuk soal no.3 : 


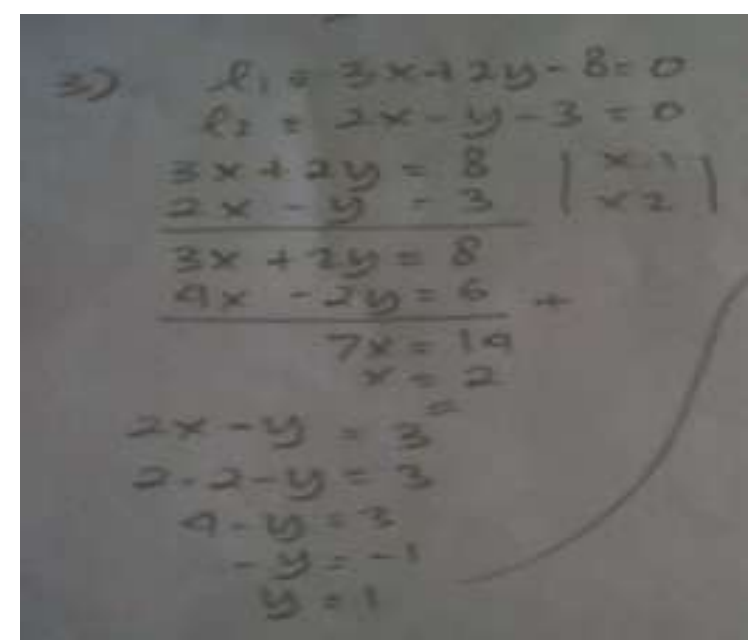

Gambar 10. Jawaba Subjek A untuk Soal No.3

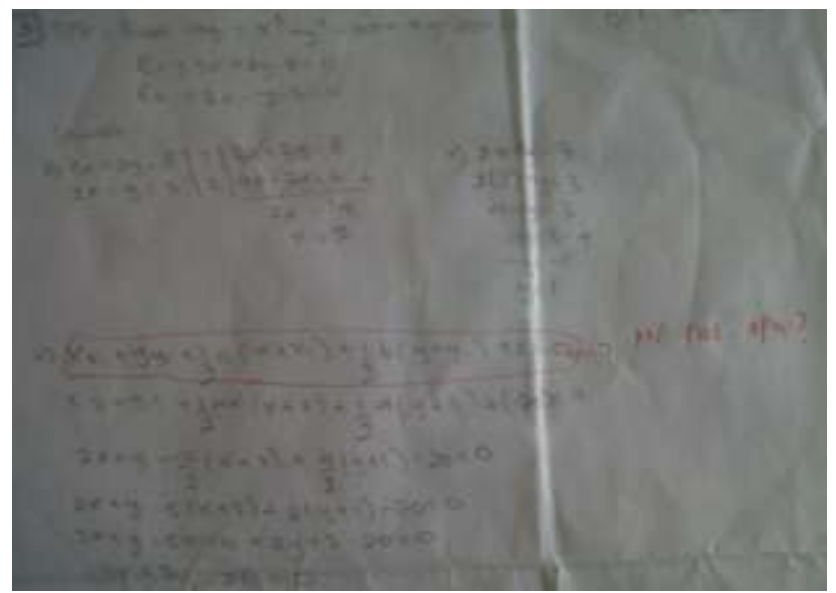

Gambar 11. Jawaban Subjek B untuk Soal No.3

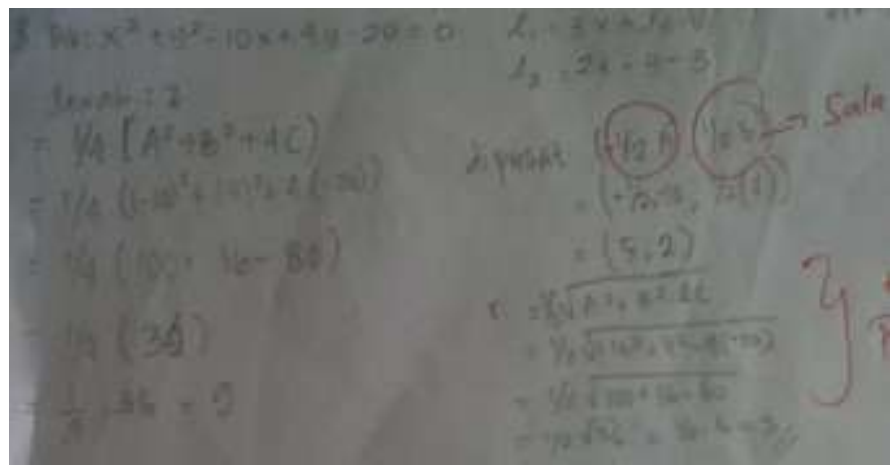

Gambar 12. Jawaban Subjek C untuk Soal No.3 
Dari jawaban di atas subjek A hanya mencari perpotongan dua garis, dan belum menjawab pertanyaan, ini dapat disimpulkan bahwa subjek A melakukan kesalahan konsep. Subjek B menuliskan mengenai apa yang diketahui dan apa yang ditanyakan ini berarti sudah memahami maksud soal, namun subjek B salah dalam menentukan rumus yang digunakan dalam menyelesaikan persamaan lingkaran. Ini dapat disimpulkan bahwa subjek B dikategorikan melakukan kesalahan sistematik, yaitu kesalahan yang berkenaan dengan pemilihan yang salah atas teknik ekstrapolasi. Berdasarkan gambar 12 di atas subjek C melakukan kesalahan dalam menentukan titik pusat, dan jari-jari lingkaran. Dalam menentukan titik pusat dan jari-jari subjek $\mathrm{C}$ salah dalam menggunakan rumus. Berdasarkan hal tersebut subjek C dikategorikan melakukan kesalahan sistematik.

4. Tentukan persamaan lingkaran yang titik pusatnya merupakan perpotongan dari garis $g_{1} \equiv 3 x+2 y-2=0$ dan $g_{2} \equiv x+2 y-$ $6=0$, dan lingkaran tersebut menyinggung garis $g_{3} \equiv 3 x+4 y+$ $2=0$ ! Jawaban:

Perpotongan $g_{1}$ dan $g_{2}=(-2,4)$

Jarak titik pusat ke $g_{3}=\frac{|3(-2)+4(4)+2|}{\sqrt{3^{2}+4^{2}}}=12 / 5$

Persamaan lingkaran:

$$
(x+2)^{2}+(x-4)^{2}=\left(\frac{12}{5}\right)^{2}
$$

Gambar 13. Soal No.4 beserta Jawaban Benar

Berikut adalah jawaban-jawaban yang diberikan oleh subjek penelitian untuk soal no. 4:

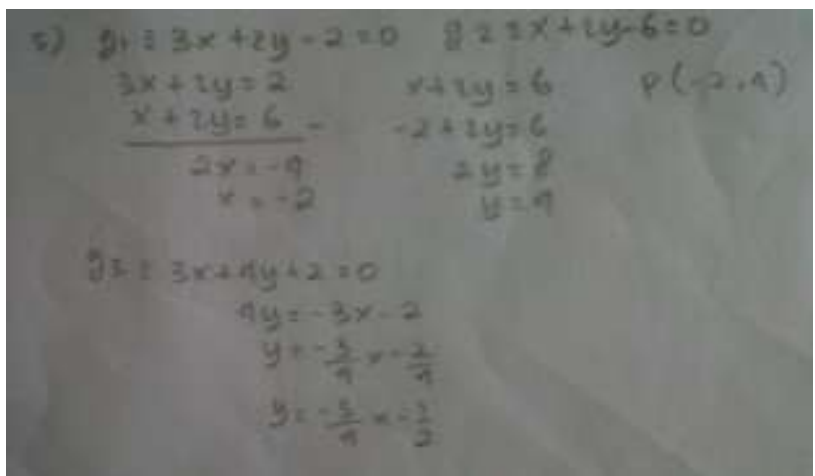

Gambar 14. Jawaban Subjek A untuk No.4 


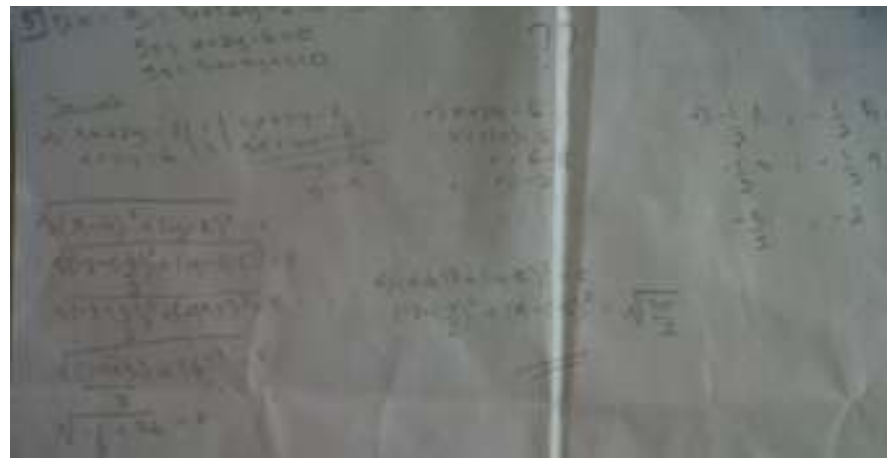

Gambar 14. Jawaban Subjek B untuk Soal No.4

Berdasarkan gambar 13 di atas subjek A baru menentukan titik potong 2 garis, namun subjek A salah dalam menentukan langkah berikutnya, dalam hal ini subjek A dikategorikan melakukan kesalahan strategi, yaitu kesalahan yang terjadi karena siswa memilih cara mengerjakan yang tidak tepat. Subjek B salah dalam menentukan rumus dalam mencari jari-jari, sehingga subjek B dikategorikan melakukan kesalahan sistematik. Sedangkan, subjek C tidak mengerjakan soal, hal ini dapat dikategorikan bahwa subjek $\mathrm{C}$ melakukan kesalahan konsep.

\section{Pembahasan}

Dari hasil identifikasi kesalahan subjek A, B, dan C, dapat disimpulkan bahwa dalam mengerjakan soal geometri analitik terdapat beberapa kesalahan yang dilakukan diantaranya adalah:

1. Kesalahan Konsep

2. Kesalahan Strategi

3. Kesalahan Hitung

4. Kesalahan Sistematik.

Kesalahan Konsep adalah kesalahan yang dilakukan mahasiswa karena tidak memahami konsep tersebut dengan baik. Aspek ini erat kaitannya dengan penguasaan materi yang dimiliki oleh mahasiswa. Dari penguasaan materi yang telah dimiliki, mahasiswa diharapkan dapat menggunakan pemahaman konsep yang dimilikinya tersebut untuk menyelesaikan persoalan yang sedang dihadapi. Kesalahan dalam memahami konsep adalah kesalahan yang dilakukan mahasiswa karena lemahnya konsep yang dikuasai. Lemahnya konsep yang dikuasai mahasiswa dapat disebabkan kurangnya partisipasi aktif ketika perkuliahan. Dalam perkuliahan geometri analitik sebagian mahasiswa hanya mendapatkan informasi dan mengerjakan soal latihan yang diberikan oleh dosen. Oleh karena itu, untuk pemahaman konsep yang lebih baik maka mahasiswa harus berpartisipasi aktif dalam perkuliahan dan dosen harus memberikan tugas berupa permasalahan dan soal mengenai konsep geometri analitik.

Kesalahan Strategi adalah kesalahan yang terjadi karena mahasiswa memilih cara mengerjakan yang tidak tepat. Kesalahan ini terjadi disebabkan oleh 
pemahaman konsep mahasiswa yang lemah. Ketika mengerjakan suatu soal mahasiswa kebingunan dalam menentukan langkah selanjutnya yang harus ditempuh, meskipun mahasiswa tersebut mengetahui konsep atau rumus yang digunakan. Untuk meminimalisir kesalahan tersebut mahasiswa dapat memperbanyak latihan soal sehingga pemahaman akan konsep tersebut dapat dikuasai.

Kesalahan hitung adalah kesalahan dalam melakukan operasi matematika. Kesalahan hitung ini disebabkan karena ketidaktelitian mahasiswa dalam mengerjakan soal meskipun mahasiswa sudah menguasai mengenai konsep yang diberikan. Kesalahan Sistematik adalah kesalahan yang berkenaan denganpemilihan yang salah atas teknik ekstrapolasi. Kesalahan sistematik yang dilakukan dalam penelitian ini adalah kesalahan dalam menggunakan rumus.

\section{PENUTUP}

\section{Kesimpulan}

Dari penelitian ini maka dapat diidentifikasi terdapat beberapa kesalahan yang dilakukan mahasiswa dalam mengerjakan soal geometri analitik materi garis dan lingkaran diantaranya adalah sebagai berikut:

1. Kesalahan konsep, yaitu kesalahan yang yang dilakukan mahasiswa karena tidak memahami konsep tersebut dengan baik.

2. Kesalahan strategi, yaitu kesalahan yang terjadi karena mahasiswa memilih cara mengerjakan yang tidak tepat.

3. Kesalahan hitung, yaitu kesalahan dalam melakukan operasi matematika.

Kesalahan Sistematik, yaitu kesalahan yang berkenaan dengan pemilihan yang salah atas teknik ekstrapolasi.

\section{Saran}

Untuk meminimalisir kesalahan yang dilakukan dalam mengerjakan soal geometri analitik bidang materi garis dan lingkaran maka mahasiswa harus berperan aktif dalam kegiatan perkuliahan, serta memperbanyak latihan soal sehingga akan meningkatkan pemahaman konsep mengenai garis dan lingkaran.

\section{UCAPAN TERIMA KASIH}

Ucapan terimakasih kami haturkan kepada LPPM Universitas Muhammadiyah Sukabumi yeng telah membiayai penelitian ini dan mahasiswa program studi pendidikan matematika sebagai subjek dalam penelitian ini.

\section{DAFTAR PUSTAKA}

Moleong,L.J. (2007). Metodologi Penelitian Kualitatif. Bandung : PT Remaja Rosdakarya.

Mulyono, A. (1999). Pendidikan Bagi Anak Berkesulitan Belajar. Jakarta: PT. Rieneka Cipta 
Ruseffendi, E.T. (1990). Pengantar kepada Membantu Guru Mengembangkan Kompetensinya dalam Pengajaran Matematika untuk Meningkatkan CBSA. Bandung: Tarsito. 